\title{
Assessment of temporal and spatial evolution of bacterial communities in a biological sand filter mesocosm treating winery wastewater
}

\author{
J.-B. Ramond, P.J. Welz, M.I. Tuffin, S.G. Burton and D.A. Cowan
}

\begin{abstract}
Aims: To assess the impact of winery wastewater (WW) on biological sand filter (BSF) bacterial community structures, and to evaluate whether BSFs can constitute alternative and valuable treatment-processes to remediate WW. Methods and Results: During 112 days, WW was used to contaminate a BSF mesocosm (length $173 \mathrm{~cm} /$ width $106 \mathrm{~cm} /$ depth $30 \mathrm{~cm}$ ). The effect of $\mathrm{WW}$ on bacterial communities of four BSF microenvironments (surface/deep, inlet/ outlet) was investigated using terminal-restriction fragment length polymorphism (T-RFLP). BSF achieved high $\mathrm{Na}(95 \cdot 1 \%)$, complete $\mathrm{Cl}$ and almost complete chemical oxygen demand (COD) (98.0\%) and phenolic (99.2\%) removals. TRFLP analysis combined with ANOSIM revealed that WW significantly modified the surface and deep BSF bacterial communities. Conclusions: BSF provided high COD, phenolic and salt removals throughout the experiment. WW-selected bacterial communities were thus able to tolerate and/or degrade WW, suggesting that community composition does not alter BSF performances. However, biomass increased significantly in the WW-impacted surface sediments, which could later lead to system clogging and should thus be monitored. Significance and Impact of the Study: BSFs constitute alternatives to constructed wetlands to treat agri effluents such as WW. To our knowledge, this study is the first unravelling the responses of BSF bacterial communities to contamination and suggests that WW-selected BSF communities maintained high removal performances.
\end{abstract}

\section{Introduction}

In South Africa, up to one billion litres of wastewater per annum is produced by the wine industry (SAWIS 2010). Winery wastewater (WW) can originate from the washing processes during vinification and bottling as well as from various other cleaning operations (such as the rinsing of wine barrels and fermentation tanks). Differences in grape varietals and the seasonality of many of the operational procedures result in significant variability in the chemical composition of cellar effluent (Malandra et al. 2003; Sheridan et al. 2011). Generally, WW has a high organic content and chemical oxygen demand (COD), with values typically reaching $5000 \mathrm{mg} \mathrm{l}^{-1}$, but values as high as 25 ooo $\mathrm{mg}^{-1}$ have been reported (Malandra et al. 2003). Because WW can have toxic effects on crop 
growth if released in agricultural areas (Mosse et al. 2010), systems are needed to reduce/eliminate the inherent organic load. A number of processes have already been tested, but most are not economically viable for small wine farms (Mosse et al. 2011).

Constructed wetlands (CWs) are potential wastewater treatment systems for small to medium sized wineries (Mosse et al. 2011) and can achieve high COD removal rates when used to treat winery effluent (e.g. Shepherd et al. 2001a; Grismer et al. 2003). They have low energy and maintenance requirements, are tolerant of seasonal input fluxes and are already used to treat and purify municipal, industrial and/or agricultural wastewaters (Haberl et al. 2003; Vymazal 2009; Mosse et al. 2011). CWs consist of a substrate (e.g. soil) that supports plants and microbial communities, with these three elements working synergistically to treat wastewater. In previously published studies on the WW treatment capacities of CWs (e.g. Grismer et al. 2001, 2003; Shepherd et al. 2001a,b), the microbial communities, which are known to play a fundamental biodegradative role (Stottmeister et al. 2003; Truu et al. 2009), were ignored and/or treated as 'black-boxes' as recently noted (Haig et al. 2011; Mosse et al. 2011). In addition, the role of plants in the biodegradation of WW is debatable as it has been shown that (i) in CWs plants do not necessarily improve BOD or COD removal (Tanner 2001), (ii) the inherent polyphenolic and salt contents render WW phytotoxic (Bryson and Barker 2002; Arienzo et al. 2009; Mosse et al. 2010, 2011) and (iii) accumulation of organic chemicals and salts in plant tissues necessitates interruptions of treatment operations for harvesting.

In this study, we thus investigated the remediation capacities of biological sand filters (BSF) mesocosms (i.e. unplanted CWs) to treat WW, principally in terms of COD, phenolic and salt removals, and to evaluate if they could constitute alternatives to CWs. Moreover, the evolution of sediment BSF bacterial communities impacted by WW was followed using terminal-restriction fragment length polymorphism (T-RFLP).

\section{Material and methods}

\section{Experimental set-up and mode of operation of the BSFs}

Two polyethylene tanks (length $173 \mathrm{~cm} /$ width $106 \mathrm{~cm} /$ depth $30 \mathrm{~cm}$; Fig. 1) were set up as pilot-scale BSFs, each filled with river sand obtained from Malmesbury (South Africa) to a volume of c. $0.5 \mathrm{~m}^{3}$ with a void space of $0.08 \mathrm{~m}^{3}$ and were inoculated in a ratio of $1: 4$ ratio with sediments from a local wetland treating WW.

\section{http://repository.uwc.ac.za}



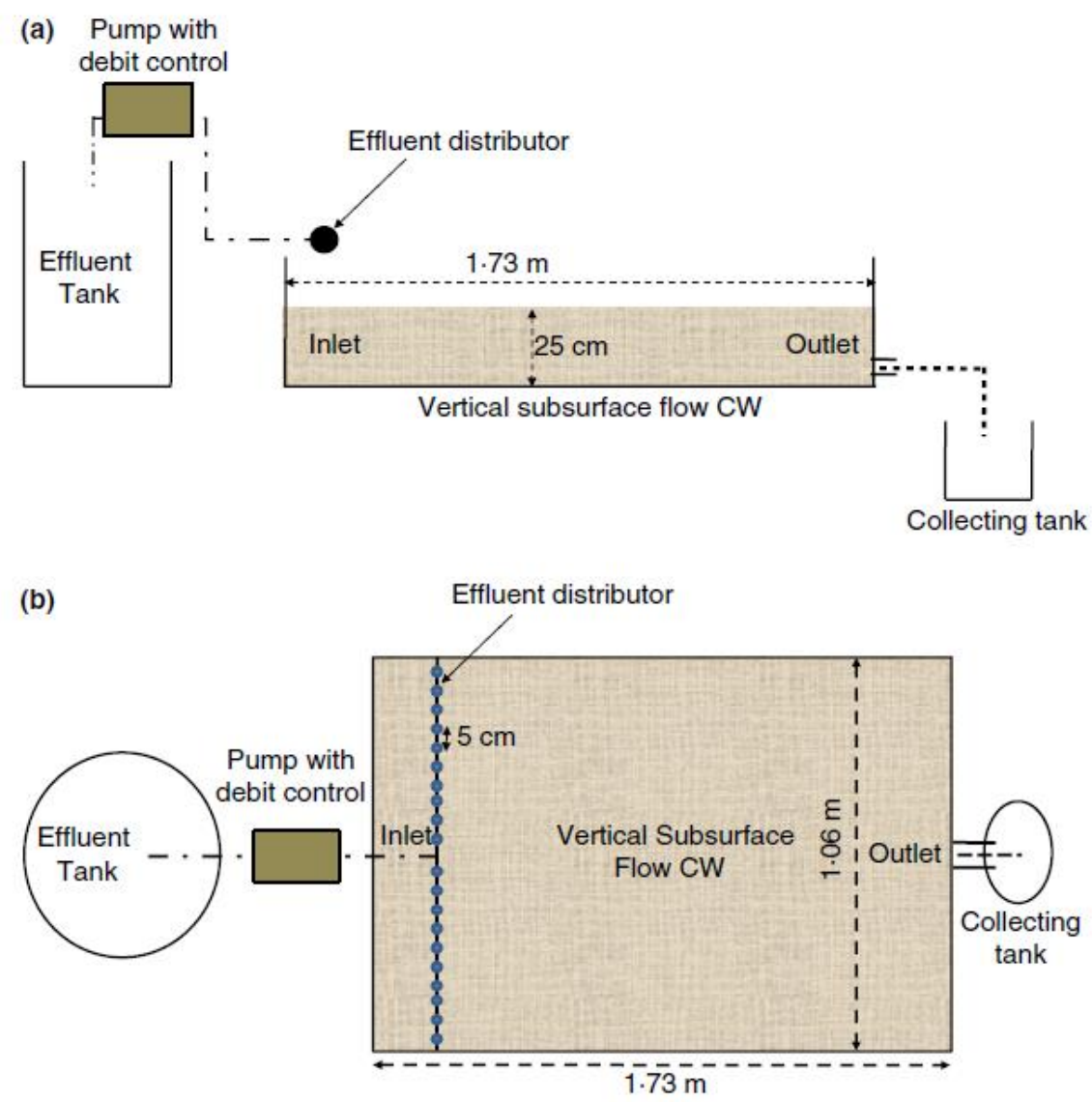

Figure 1 Schematic representation of the pilot-scale biological sand filters. (a) Lateral view, (b) View from above (Adapted from Ramond et al. 2012).

The final BSF sediment composition consisted of $1 \%$ clay, $7 \%$ silt, $4 \%$ fine sand, $12 \%$ medium sand and $76 \%$ coarse sand; with $6 \mathrm{mg} \mathrm{kg}^{-1} \mathrm{P}, 1.9 \mathrm{~g} \mathrm{~kg}^{-1} \mathrm{C}, 0 \cdot 07 \mathrm{cmol}(+) \mathrm{kg}^{-1}$ $\mathrm{Na}$, $0.05 \mathrm{cmol}(+) \mathrm{kg}^{-1} \mathrm{~K}, 1.64 \mathrm{cmol}(+) \mathrm{kg}^{-1} \mathrm{Ca}$, $0.21 \mathrm{cmol}(+) \mathrm{kg}^{-1} \mathrm{Mg}, 0.61 \mathrm{mg} \mathrm{kg}^{-1} \mathrm{Cu}$, $1.0 \mathrm{mg} \mathrm{kg}{ }^{-1} \mathrm{Zn}, 1.9 \mathrm{mg} \mathrm{kg}^{-1} \mathrm{Mn}, 0.10 \mathrm{mg} \mathrm{kg}^{-1} \mathrm{~B}, 63.03 \mathrm{mg} \mathrm{kg}{ }^{-1} \mathrm{Fe}$ and $7.42 \mathrm{mg} \mathrm{kg}^{-}$ $1 \mathrm{~S}$.

The BSFs were operated in a mixed vertical (VSSF) and horizontal (HSSF) subsurface flow mode (Stottmeister et al. 2003) and subjected to bi-weekly inundation followed by gradient-directed drainage to ensure that the mode of operation was biased towards classical VSSF. This type of BSF is considered to produce substrate degradation rates superior to a HSSF set-up, due to the maintenance of high redox potentials that facilitate aerobic microbial processes (Faulwetter et al. 2009). The hydraulic retention times of the BSFs were estimated to be 22 days, thus were functioning as slow sand filters (Haig et al. 2011).

Prior to amendment with WW (this study), the BSFs were drip-fed with basal nutrients consisting of $0.3 \mathrm{~g}$ glucose and $0.3 \mathrm{~g}$ yeast extract in $12.5 \mathrm{l}$ tap water at $0.67 \mathrm{lmin}^{-1}$ for a period of 100 days as detailed previously (Ramond et al. 2012). Briefly, this nutrientfeeding regime was designed to provide a $\mathrm{C} / \mathrm{N} / \mathrm{P}$ ratio of $32: 7: 1$, with a low 
carbon supply (influent $\mathrm{COD}=24 \mathrm{mg} \mathrm{l}^{-1}$ ) and nonlimited nitrogen $(\mathrm{N})$ and phosphorous (P) sources. The objective was to maintain an oligotrophic state, as oligotrophic systems are more reactive to changes in nutrient status, such as WW contamination (Verhoeven et al. 2006) and establish similar microbial community patterns in the BSFs (Ramond et al. 2012). Drip-feeding of BSF A with the $12.5 \mathrm{l}$ basal nutrient solution was continued during the experimental period, during which BSF B was amended with winery effluent diluted in a $1: 5$ ratio (2.5 l of winery effluent plus nutrients made up to $12.5 \mathrm{l}$ in tap water) bi-weekly for a period of 112 days. This procedure ensured that the volume and nutrient concentration of both the control and the experimental BSFs remained constant throughout the equilibration and experimental periods. It corresponded to an organic loading rate of 54 gCOD m3 day ${ }^{-1}$.

\section{Influent and effluent analysis}

The influent WW and the effluent of both BSFs were characterized at day 0, 21, 56, 84 and 112 (Table 1). Outflow of effluents was observed $15 \mathrm{~min}$ after the start of feeding or contamination. The effluent samples analysed corresponded to the total volume of effluent collected between 1 and $2 \mathrm{~h}$ after the initiation of feeding. Indeed, it has previously been established that outflow was consistent during this period (data not shown). COD was quantified using a Hanna instruments (Smithfield, RI, USA) C214 multiparameter bench photometer, a Hanna C980o digester and both low-range (1-150 $\mathrm{mg} \mathrm{l}^{\mathbf{1}}$ : HI93754A-25) and medium-range (o-1500 $\mathrm{mg} \mathrm{l}^{-1}$ : HI93754B-25) COD kits, following the manufacturer's instructions. Total phenolic concentration was determined using the FolinCiocalteau (FC) micro method for total phenol in wine, based on the method reported by Slinkard and Singleton (1977). Gallic acid standards were prepared in-house, and results were expressed as $\mathrm{mg}^{\mathbf{- 1}}$ in gallic acid equivalents (GAE) determined from a standard graph.

Sodium and chloride concentrations in the effluents were analysed by Bemlab (Pty) Ltd (Strand, Western Cape, South Africa). Cl was determined titrimetrically using a standardized $0.05 \mathrm{~mol} \mathrm{l}^{\mathbf{- 1}}$ solution of silver nitrate. Na was determined using a varian inductively coupled plasma - optical emission spectrometer (ICP-OES). 
Table 1 Effluents characterization of the constructed wetland: control (basal feeding) and winery waste (WW) contaminated

\begin{tabular}{|c|c|c|c|c|c|c|}
\hline Days & Constructed wetland & $\mathrm{pH}$ & $\operatorname{COD}\left(\mathrm{mg} \mathrm{I}^{-1}\right)$ & Total phenolics (mg GAE I-1) & $\mathrm{Na}\left(\mathrm{mg} \mathrm{l}^{-1}\right)$ & $\mathrm{Cl}\left(\mathrm{mg} \mathrm{I}^{-1}\right)$ \\
\hline \multirow[t]{2}{*}{$0 / 1 h^{*}$} & Control & $7 \cdot 2$ & 35 & 1.75 & $12 \cdot 75$ & $35 \cdot 24$ \\
\hline & WW contaminated & $8 \cdot 2$ & 61 & $2 \cdot 50$ & $14 \cdot 15$ & $35 \cdot 25$ \\
\hline \multirow[t]{2}{*}{21} & Control & $7 \cdot 4$ & 70 & 1.64 & $10 \cdot 16$ & $26 \cdot 43$ \\
\hline & WW contaminated & 7.6 & 61 & 1.95 & 12.75 & 26.43 \\
\hline \multirow[t]{2}{*}{56} & Control & $7 \cdot 2$ & 51 & 1.66 & $9 \cdot 24$ & $35 \cdot 24$ \\
\hline & WW contaminated & $7 \cdot 6$ & 74 & 2.59 & $19 \cdot 17$ & $35 \cdot 24$ \\
\hline \multirow[t]{2}{*}{84} & Control & $7 \cdot 2$ & 34 & 1.23 & 9.57 & $26 \cdot 43$ \\
\hline & WW contaminated & 7.5 & 101 & 1.86 & 19.94 & $34 \cdot 24$ \\
\hline \multirow[t]{2}{*}{112} & Control & $7 \cdot 2$ & 17 & 1.34 & $10 \cdot 13$ & $35 \cdot 24$ \\
\hline & WW contaminated & 7.4 & 138 & 2.00 & 9.32 & 26.43 \\
\hline
\end{tabular}

COD, chemical oxygen demand; GAE, gallic acid equivalents; WW, winery wastewater.

*The initial sample of biological sand filter B was collected one hour $(1 \mathrm{~h})$ after the inception of the pollutant challenge.

\section{Sediment sampling, pH and salt concentrations}

A 30-mm-diameter PVC sediment corer was used to recover samples without major disturbance of the sediment stratification. Triplicate sample cores were taken from the inlet and the outlet of each BSF, at the start of the experiment (Day 0) and after 7, 21, 56, 84 and 112 days of the experiment. For BSF B (WW-amended), the initial sample was collected one hour $(1 \mathrm{~h})$ after the inception of the pollutant challenge to assess the immediate impact of allochthonous bacteria present in the WW (Malandra et al. 2003). Composite surface $(\mathrm{O}-3 \mathrm{~cm})$ and deep $\left(15^{-20} \mathrm{~cm}\right)$ fractions were thoroughly mixed, and c. $1 \mathrm{~g}$ wet weight sediment of each was retained at $-20^{\circ} \mathrm{C}$ for subsequent molecular analysis.

The $\mathrm{pH}$ of the wetland soils was assessed according to the method used by Hartman et al. (2008). Equal quantities of de-ionised water and soil were mixed and the $\mathrm{pH}$ of the slurries determined using a Eutech Cyberscan $300 \mathrm{pH}$ metre and probe. Salt content $(\mathrm{Na}$ and $\mathrm{Cl}$ ) in sediment samples was measured using a Eurovector EA300o instrument at the Soil Science Faculty of the University of Stellenbosch (Western Cape, South Africa).

\section{Sediment and winery wastewater DNA extraction procedures}

Total DNA from the BSF sediments was extracted from $0.5 \mathrm{~g}$ of samples (wet weight) with the Powersoil DNA isolation kit according to the manufacturer's instructions (MoBio laboratories, Solana Beach, CA, USA). To extract total DNA from the WW, $100 \mathrm{ml}$ of WW was filtered using 0.45-lm membranes (HPLV047; Millipore, Bedford, MA, USA) and a Sartorius filtration system. Half of the filter was then cut into small pieces using a sterile blade and DNA was extracted from it using the Powersoil DNA isolation kit according to the manufacturer's instructions (MoBio laboratories). The concentration of DNA in the samples was measured with a NanoDrop spectrophotometer (NanoDrop Technologies, Montchanin, DE, USA) and was used as a proxy of microbial biomass as described by Mastorp et al. (2000). It was expressed in ng DNA extracted per gram dry sediment to correct for differences in soil moisture contents. 


\section{PCR amplification, purification and restriction digestion}

All polymerase chain reactions (PCRs) were carried out in a Perkin Elmer Thermocycler (Gene Amp PCR system 6700; Perkin Elmer Inc., Waltham, MA, USA). Bacterial 16S rRNA genes were amplified using the universal primers E9F ( 5 '-GAGTTTGATCCTGGCTCAG- 3 ') and U1510R (5'-GGTTACCTTGTTACGACTT- $\left.3^{\prime}\right)$. Each PCR contained 19 PCR buffer, 0.2 U DreamTaq $^{\mathrm{TM}}$ polymerase (Fermentas, Maryland, NY, USA), $200 \mathrm{lmol}^{\mathbf{- 1}}$ of each dNTP, $0.5 \mathrm{lmol} \mathrm{l}^{-1}$ of each primer, $0 \cdot 1 \%$ BSA and 20-30 ng of total DNA. PCR amplification was carried out as follows: $4 \mathrm{~min}$ at $94^{\circ} \mathrm{C}$ for denaturation; 30 cycles of $30 \mathrm{~s}$ at $94^{\circ} \mathrm{C}, 30 \mathrm{~s}$ annealing at $52^{\circ} \mathrm{C}$ and $105 \mathrm{~s}$ at $72^{\circ} \mathrm{C}$; and a final elongation step of $10 \mathrm{~min}$ at $72^{\circ} \mathrm{C}$. To perform T-RFLP, the primer E9F was $5^{\prime}$-end FAM-labelled and the PCR products were purified using the GFX ${ }^{\mathrm{TM}}$ PCR DNA and gel band purification kit as directed by the supplier (GE Healthcare, Buckinghamshire, UK). Purified PCR products (100 ng) were digested with the restriction enzyme HaeIII at $37^{\circ} \mathrm{C}$ for $3 \mathrm{~h}$ and subjected to T-RFLP analysis.

\section{T-RFLP analysis}

The evolution of the bacterial community structure was assessed by T-RFLP fingerprinting using the $16 \mathrm{~S}$ rRNA gene as a marker. The precise length of T-RFs was determined by capillary electrophoresis using the Applied Biosystems DNA Sequencer 3130 (Applied Biosystems, Foster City, CA, USA) and according to the molecular weight standard Rox1.1 (with an acceptable error of $\pm 1 \mathrm{bp}$ ). T-RFLP patterns and quality were analysed using TM the freeware PeakScanner (version 1.0) (Applied Biosystems, https://products.appliedbiosystems.com). Peak height was used to characterize each unique T-RF, and valid T-RF peaks (between 35 and $500 \mathrm{bp}$ ) from triplicate T-RFLP profiles were identified, compiled and aligned to produce large data matrices using the online software T-REX (http://trex.biohpc.org/; Culman et al. 2009). T-RFs with intensities lower than $1 \%$, which may have originated from background interference, were excluded from the matrices. The term OTU is used to refer to individual restriction fragments in T-RFLP patterns (based on variation in the 16S rRNA gene), with recognition that each OTU may comprise more than one distinct bacterial ribotype (Blackwood et al. 2007).

\section{Statistical analysis}

To visualize the effect of winery effluent on the bacterial community profile, nonmetric multidimensional scaling (MDS) plots were created using Bray-Curtis similarity matrices of square-root transformed data with the software Primer 6 (Primer-E Ltd, Plymouth, UK). Two-dimensional MDS plots were used, where the distance between points reflects the degree of similarity between the microbial community profiles in the samples. In these plots, the percentage of similarity is displayed by ellipses (Fig. 2). An analysis of similarity (ANOSIM), performed on the resemblance matrix, was used to test for differences in bacterial community structure between predefined groups (in this study control vs WW-impacted communities; Clarke 1993).

\section{http://repository.uwc.ac.za}


Figure 2 Two-dimensional plot of nonmetric multidimensional scaling analysis of the evolution of the constructed wetland sediment microbial community structures. (a) In the surface sediments and (b) In the deep sediments. The ellipses around the samples describe their level of similarity (black 20\% dashed black $40 \%$; grey $60 \%$ ). Winery wastewater; $\Delta$ : Control inlet; $\circ$ : Control outlet; $\mathbf{\Lambda}$ : Inlet winery effluent contaminated; -: Outlet winery effluent contaminated. Numbers indicate the day of sampling relative to the start of the experiment $(0 / 1 \mathrm{~h}, 7,21$, 56,84 and 112 ).
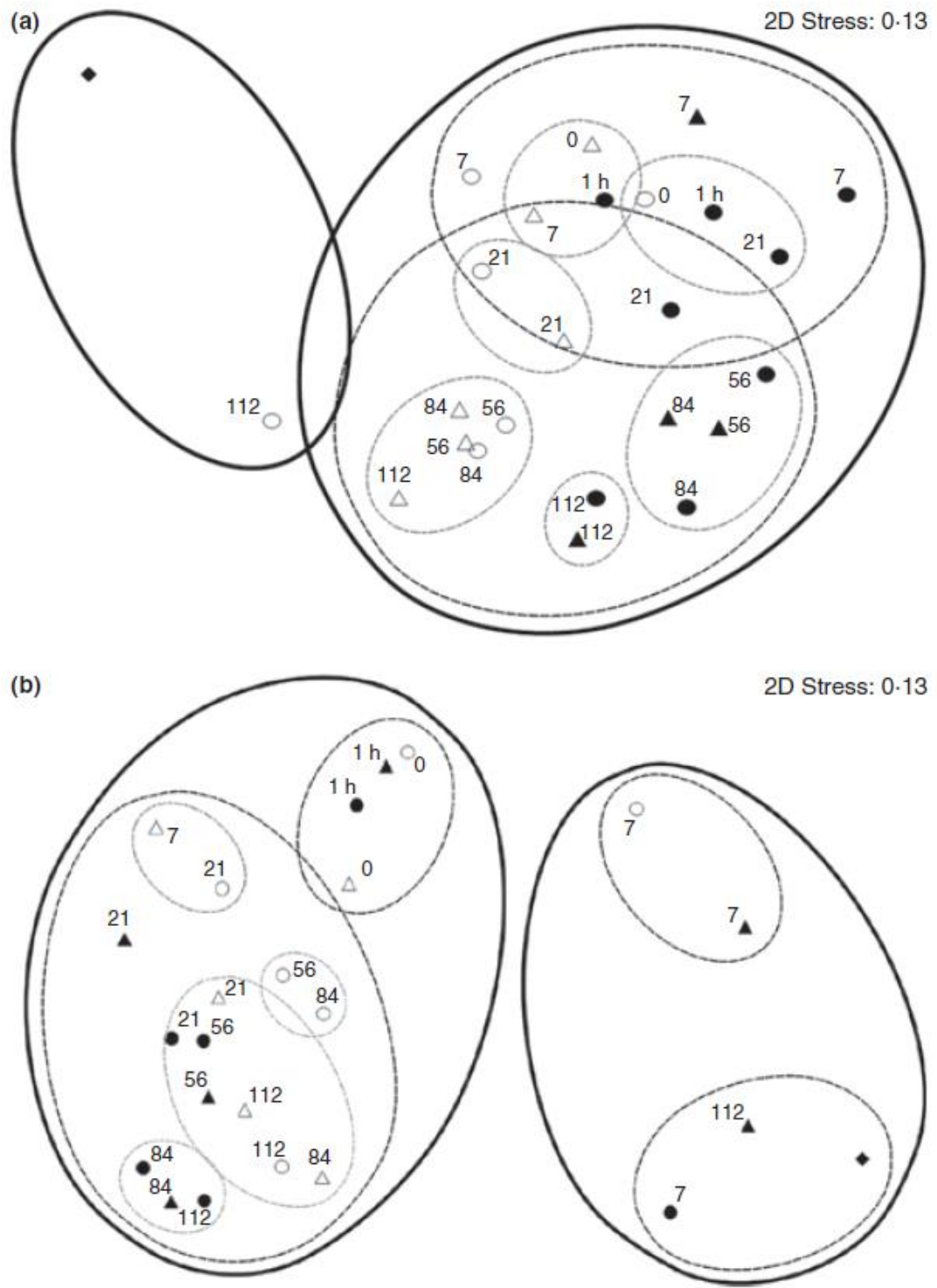

2D Stress: 0.13

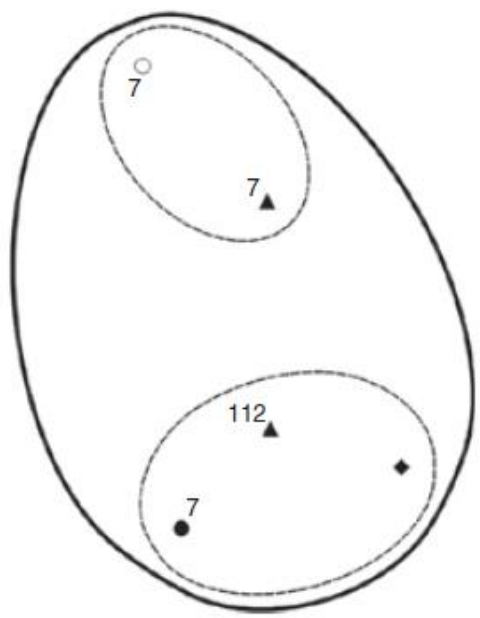

We conducted analysis of variance (ANOVA) to assess significant difference $(\mathrm{P}<0 \cdot 05)$ between the abiotic variables and the microbial biomass of the control and WWamended BFSs with the PAST software (Hammer et al. 2001).

\section{Results}

\section{Remediation capacities of BSF mesocosms}

COD is commonly used to evaluate the organic load in wastewaters (e.g. Welz et al. 2012). During the 112 days experiment, the average COD value of the effluent from

the WW-contaminated BSF B $\left(87 \cdot 0 \pm 32 \cdot 9 \mathrm{mg} \mathrm{l}^{-1}\right.$; Table 2) was not significantly higher than that of the control BSF A $\left(41 \cdot 4 \pm 20 \cdot 0 \mathrm{mg} \mathrm{l}^{-1}\right.$; ANOVA: $\left.\mathrm{F}=2 \cdot 697 ; \mathrm{P}=0.360\right)$; and an average COD removal efficiency of $98 \cdot 1 \%$ was achieved by BSF B (Table 2). The average phenolic concentration of the influent WW was $85 \cdot 8( \pm 22 \cdot 6) \mathrm{mg} \mathrm{GAE}^{-1}$ (Table 2) and the quantity of phenolics detected in the effluents of BSF B was on average 12.2 ( $\pm \mathrm{O} \cdot 3$ ) $\mathrm{mg} \mathrm{GAE}^{-}$(Table 2), not significantly different than that of the control BSF A 
(ANOVA: $\mathrm{F}=2 \cdot 254 ; \mathrm{P}=0 \cdot 450$ ). Because phenolics were not present in the influent of the control BSF A, it is suggested that the amount of phenolics present in BSF A effluents was also contributing to the phenolic titres in BSF B effluents (probably by originating from the leaching of soil components). Thus, BSF B achieved almost complete removal (99.2\%, Table 2) of the WW phenolics.

Table 2 Average removal rate and influent and effluent wastewater qualities for the WW-amended BSF B during 112 days

\begin{tabular}{|c|c|c|c|}
\hline Parameter & Influent & Effluent & Removal* (\%) \\
\hline $\operatorname{COD}\left(\mathrm{mg} \mathrm{l}^{-1}\right)$ & $2304.4 \pm 628.8$ & $87 \cdot 0 \pm 32 \cdot 9$ & 98.0 \\
\hline 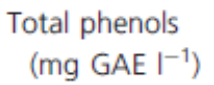 & $85 \cdot 8 \pm 22 \cdot 6$ & $2 \cdot 2 \pm 0.3$ & $99 \cdot 2$ \\
\hline $\mathrm{pH}$ & $4 \cdot 2$ & 7.7 & N.A. \\
\hline $\mathrm{Na}\left(\mathrm{mg} \mathrm{l}^{-1}\right)$ & $102 \cdot 1$ & $15 \cdot 0 \pm 4.5$ & $95 \cdot 1$ \\
\hline $\mathrm{Cl}\left(\mathrm{mg} \mathrm{l}^{-1}\right)$ & $215 \cdot 0$ & $31.5 \pm 4.7$ & 100 \\
\hline
\end{tabular}

N.A., not applicable; BSF, biological sand filter; COD, chemical oxygen demand; GAE, gallic acid equivalents; WW, winery wastewater.

Removal efficiency $\%=100-[((B S F$ B effluent concentration - BSF A effluent concentration)/BSF B influent concentration)*100].

*The mean effluent concentrations from the control BSF A presented in Table 2 were taken into account to determine the removal rates of BSF B.

The average $\mathrm{Na}$ concentration was significantly higher in the BSF B effluent than in the control BSF A effluent (ANOVA: $\mathrm{F}=10 \cdot 389 ; \mathrm{P}=0 \cdot 045)$, which was not the case for $\mathrm{Cl}(\mathrm{P}=$ 0.948). Also, a build-up of sodium in the sediments of BSF B was observed after 112 days in the superficial outlet but not at the inlet, while chloride levels diminished in the sediments at all sampling sites (Table S1). The pH of the influent WW was low (4.2; Table 2). In contrast, the effluent $\mathrm{pH}$ of BSF $\mathrm{B}$ was neutral and/or slightly alkaline throughout the experiment (Tables 1 and 2) and significantly higher than in the control effluent (ANOVA: $\mathrm{F}=12 \cdot 25 ; \mathrm{P}=$ $0 \cdot 032)$.

\section{Impact of winery effluent on BSF bacterial communities}

T-RFLP targeting the $16 \mathrm{~S}$ rRNA genes in total extracted DNA was used to monitor the evolution and response of pilot-scale BSF microbial communities to WW. The ranked order of similarities between T-RFLP profiles (i.e. between microbial community structures) is graphically represented in MDS plots for the surface and deep sediment microbial communities (Fig. 2a,b, respectively). The day o samples clustered strongly in the nMDSplots, confirming that the equilibration phase resulted in the establishment of similar bacterial communities in BSFs A and B, thereby ensuring the relevance of subsequent experimental comparisons (Ramond et al. 2012). Micro-organisms being present in South African winery effluents (Malandra et al. 2003), it was appropriate to evaluate the potential of these allochthonous micro-organisms as colonizers of the BSFs after deposition in the sediment matrix. The WW microbial community, consisting of 21 OTUs (data not shown), was therefore included in the analyses (Fig. 2). Finally, the evolution of the microbial biomass in the BSF sediments was evaluated by the amount of DNA extracted

\section{http://repository.uwc.ac.za}


per ng of dry sediments (Mastorp et al. 2000; Fig. 3) as in such set-up biomass growth could lead to clogging and thus malfunction (Mosse et al. 2011).

\section{Evolution of the surface sediment BSF bacterial communities}

The MDS plot depicts that from day 7 onwards, the points representing the inlet and outlet WW-impacted microbial communities are distinctly separated from those of the control (Fig. 2a), demonstrating that WW significantly impacted the BSF surface communities (ANOSIM, Global $\mathrm{R}=0.527, \quad \mathrm{P}=0.001$ ). In addition, the 'points' representing the WW-impacted communities and the WW itself are well separated on the MDS plot (Fig. 2a). This suggests that the allochthonous bacteria present in the WW did not multiply in these sediments. From day 56, the points representing the inlet and outlet WW-impacted communities are close on the MDS plot, sharing over $60 \%$ similarity in terms of diversity (Fig. 2a). Thus, from day 56 until the end of the pollutant challenge (day 112), the selection/adaption of the surface microbial communities induced by WW contamination was independent of their spatial localization in BSF B. Similarly, the biomass increased in the superficial sediments in both BSFs during the experiment and was significantly higher in the WW-impacted BSF B than in the control from day 56 and until the end of the 112 day experiment (Fig. 3a,b, respectively).

\section{Evolution of the deep sediment BSF bacterial communities}

The communities from the inlet and outlet of the control and WW-impacted BSFs shared c. $20 \%$ similarity at day 7 (Fig. 2b). This indicated that the deep sediment microbial communities were immediately and severely impacted by WW. ANOSIM analyses revealed also that WW modified the deep sediment communities from day 84 onwards (ANOSIM, Global $\mathrm{R}=0.469, \mathrm{P}<0.05$ ). In contrast to the surface, after 112 days of contamination, distinctly different communities evolved at the inlet and outlet of the deep sediments from the WW-amended BSF (Fig. 2b). Communities from the experimental and control BSFs shared over $40 \%$ similarity at the outlet, but less than $20 \%$ similarity at the inlet. Twice during the course of the experiment, the communities from the WW-impacted BSF (i.e. days 7 outlet and day 112 inlet) and the WW itself shared 40\% similarity. However, after 112 days, the biomass was significantly higher in the deep inlet sediment of the control BSF A when compared to that of BSF B and not different significantly different in the deep outlet sediments (Fig. 3c,d). Together, these results suggested that bacteria present in the WW likely migrated through the sediment matrix by vertical flow to the deep sediments, without proliferating. 

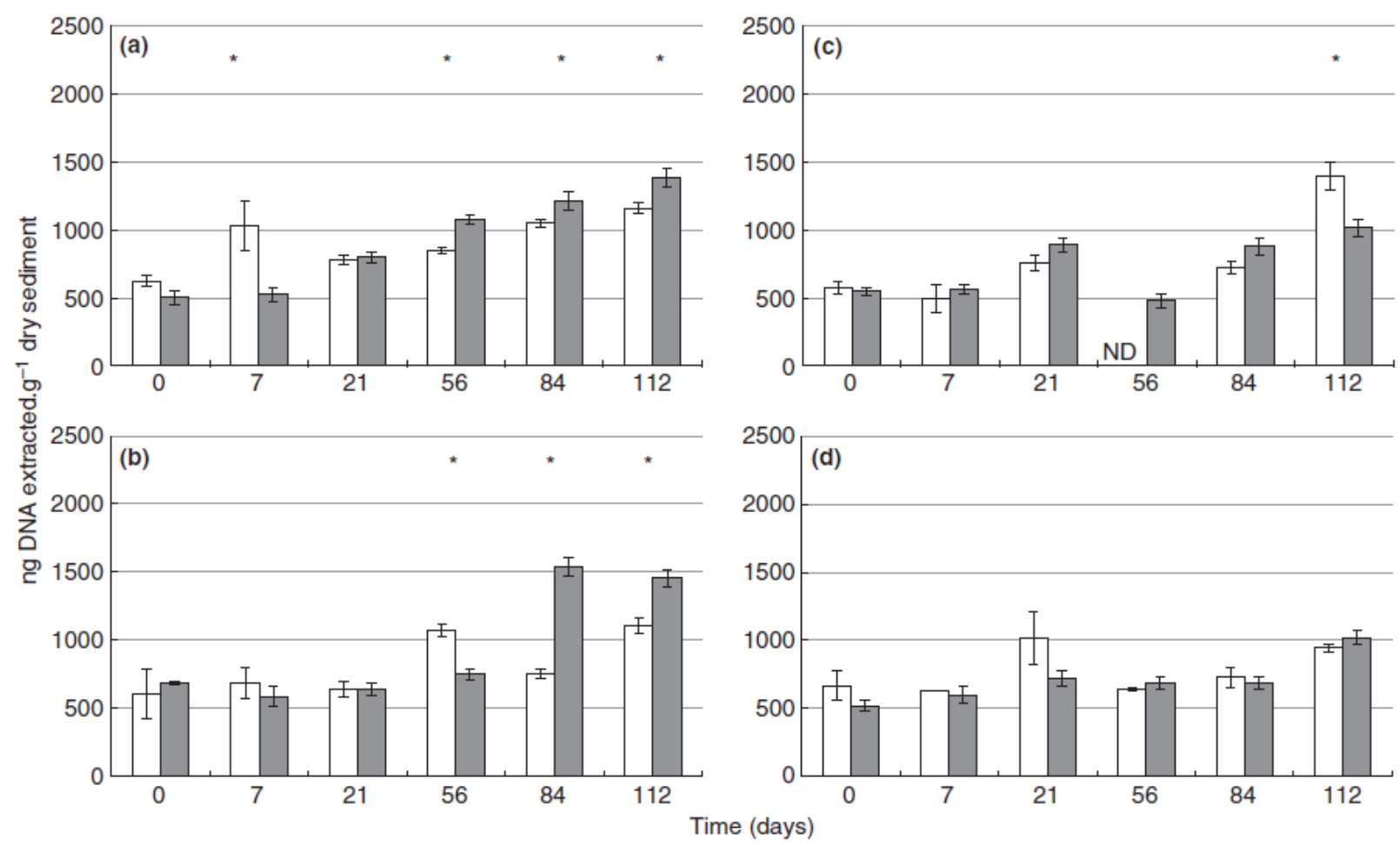

Figure 3 Biomass evolution (in ng DNA extracted per gram dry sediments) in the sediments of the control (white histograms) and the winery wastewater-impacted biological sand filters (grey histograms). (a) Surface inlet sediment, (b) Surface outlet sediments, (c) Deep inlet sediments and (d) Deep outlet sediments. Error bars indicate the standard deviation. *Values are significantly different (one-way repeated-measures ANOvA; $P<0.05$ ). ND (not determined) indicates that no data are available.

\section{Discussion}

WW remediation capacity of BSF mesocosms In this study, the diluted WW used to contaminate BSF B was characterized by high COD and salt concentrations and a low $\mathrm{pH}$ that is typical of South African WW (Malandra et al. 2003; Sheridan et al. 2011). The phenolic content was significantly higher than values previously reported in South Africa (from 0 to $37 \cdot 1 \pm 10 \cdot 3 \mathrm{mg} \mathrm{l}^{-1}$; Malandra et al. 2003; Sheridan et al. 2011). All these characteristics have the potential to alter the environmental processes, and thus the BSF removal performances, which are predominantly driven by microbial communities (such as N cycling) in BSFs (e.g. Francis 1982; Lucassen et al. 2002; Moussa et al. 2006).

Varied COD removal performances have been achieved and reported in CWs treating cellar effluent. With WW influent CODs ranging from 2040 to $4850 \mathrm{mg} \mathrm{l}^{-1}$, Shepherd et al. (2001a) reported an average COD removal rate of $98 \%$ in planted, pilot-scale subsurface-flow CWs combined with an uploading sand prefilter, while Serrano et al. (2010) reported an average removal efficiency of $73.3 \%$ in a full-scale, hybrid CW (without any pretreatments) impacted by WW with influent CODs ranging from 422 to $2178 \mathrm{mg} \mathrm{\mathbf {l } ^ { - 1 }}$. In this study, effective COD removal (98.0\%) was achieved without pretreatment, in the absence of plants, and with influent CODs averaging $2304( \pm 628 \cdot 8)$ $\mathrm{mg} \mathrm{l}^{\mathbf{- 1}}$ (Table 2). Therefore, the BSF used in this study performed very effectively COD removals in comparison with CW systems.

\section{http://repository.uwc.ac.za}


Phenolic compounds, including tannins, that emanate from the seeds, skins and piths of grapes are commonly found in WW (Grismer et al. 2003). These compounds are recalcitrant in the environment, with slow biodegradation rates and potentially high toxicity (Shepherd et al. 2001a; Mosse et al. 2010; Serrano et al. 2010). In this study, almost complete removal of phenolics (99.2\%, Table 2) was achieved, despite high influent concentrations. The ability of an unplanted model to achieve this demonstrates the potential of the BSFs to be used for treating other agricultural effluents presenting high COD and organic contents, such as olive mill wastewater (OMWW) (Herouvim et al. 2011). In BSFs, both the substrate and the microbial communities play an active role in (bio)remediation of organic-laden effluent (Welz et al. 2012): the soil matrix, depending on its composition, can facilitate abiotic oxidation of organic compounds, which is often coupled to the reduction in iron and/or manganese (Lehmann et al. 1986; Polubesova et al. 2010), and microbial communities, via respiration and fermentation processes, play an essential role in the mineralization of organic pollutants into basic molecules such as carbon dioxide, nitrogen gas and water (Faulwetter et al. 2009).

One of the major environmental concerns relevant to the release of WW is the salt content, as soil and water form the final two repositories of all salts discharged into the environment. $\mathrm{Na}^{+}$and $\mathrm{Cl}^{-}$ions can both have detrimental effects on plant growth and soil properties and can cause salination of inland aquatic habitats (Bryson and Barker 2002; Ramakrishna and Viraraghavan 2005). Removal of these ions in BSF involves principally abiotic processes as micro-organisms are not able to metabolize them. Indeed, halophilic and/or halotolerant micro-organisms adapt to the osmotic stress caused by high salinity either (i) by active transport of these ions out of their cell, (ii) the accumulation of compatible solutes in their cytoplasm or (iii) by the formation of EPS/biofilms (Madigan and Oren 1999; Zhang et al. 2011). Both soil particles and $\mathrm{Cl}$ anions are negatively charged (Ramakrishna and Viraraghavan 2005), therefore it is expected that chloride anions would not be retained in BSF systems. In this study, virtually all the $\mathrm{Cl}$ in the $\mathrm{WW}$ was removed through the BSF substrate. Although $\mathrm{Cl}$ volatilization studies were not conducted, this would be the most plausible explanation/mechanism for the total $\mathrm{Cl}$ removal. In contrast, the sodium content of the WW influent was only reduced by $95 \cdot 1 \%$ (Table 2), probably by sediment trapping/sorption in the surface outlet compartment (Table S1). Indeed, the negatively charged soil particles can adsorb $\mathrm{Na}^{+}$by cation exchange sites with the naturally present calcium and magnesium cations (Ramakrishna and Viraraghavan 2005). The residual effluent concentration of sodium is concerning, and a combination of pre- or post-treatment processes for sodium reduction is therefore recommended for BSFs used to treat WW.

The $\mathrm{pH}(4 \cdot 2)$ of the WW used in this study was similar to that of other South African WW where acetic acid is generally the dominant organic acid (Malandra et al. 2003; Sheridan et al. 2011). As the effect of acidic effluent on the $\mathrm{pH}$ of sediments is dependent on the chemical composition of the substrate, these results suggest that either the soil matrix of

\section{http://repository.uwc.ac.za}


the BSF imparted a strong buffering capacity (Yong et al. 1990), and/or that the main contributor to the acidity of the WW was metabolized. Indeed, as a substrate, acetate is readily assimilated by environmental bacteria, particularly during methanogenesis (Ferry 1992). It should be noted that the intermediate and slightly alkaline $\mathrm{pH}$ values observed in all the sediments were optimal for WW biodegradation as most soil bacteria function best under these near-neutral conditions (Verheye 2002).

\section{Impact of winery effluent on BSF bacterial communities}

In a 2 week microcosm experiment, Mengoni et al. (2005) established strong correlations between the dynamics shown by RNA- and DNA-based T-RFLP profiles, despite the fact that these profiles did not overlap completely. As this experiment was designed to continue over an extended period (112 days), T-RFLP targeting the 16S rRNA genes in total extracted DNA rather than in total mRNA was chosen to assess the evolution and response of pilot-scale BSF microbial communities to WW.

Micro-organisms play key roles in most of the biogeochemical cycles, making them key components of any bioremediatory processes (for review, see Gadd 2010), particularly in BSF systems where the macrophyte compartment is nonexistent. When impacted by contaminants, microbial communities are either resistant to the contaminant (i.e. the community structure remains unaltered), resilient (i.e. the community structure changes initially, but is later restored to the original), or sensitive (i.e. the community structure is permanently modified) (Allison and Martiny 2008). The modification of sensitive microbial communities is very likely to result in an alteration in environmental process rates. For (micro)biological treatment processes to remain effective, all the essential ecosystem processes and cycles must be sustained (or enhanced). For this study, we assumed that reliable organic removal efficiencies could be achieved if the microbial communities were able to conserve the basic biogeochemical processes necessary for the bioremediation of WW (Yagi et al. 2010), because 'abiotic' removal processes, such as sorption and precipitation, would ultimately have decreasing efficiencies due to the saturation of potential binding sites or the declining abundance of any possible 'precipitating partner'.

Low $\mathrm{pH}$ and high organic (including ethanol and phenolic compounds) and salt contents, which characterize the WW used in this study, have all been shown to induce structural changes in environmental microbial communities (e.g. Lucassen et al. 2002; Moussa et al. 2006; Feris et al. 2008). And this study showed that the BSF microbial communities were responsive to the impact of WW (Fig. 2), resulting in changes in the community structure in the four microenvironments studied. However, while the community structure changed over time, the remediation capacity remained high, with COD and phenolic removal rates of $>98 \%$ throughout the experimental period. These results strongly suggest that there was a selection of functionally redundant microbial communities (Allison and Martiny 2008). The significant biomass increase observed in the WW-impacted BSF surface sediments (Fig. 3) confirmed in the BSF the growth of an adapted microbial community to WW. However, it should be noted that it could lead to

\section{http://repository.uwc.ac.za}


the alteration of its treatment capacities due to clogging and should therefore be monitored (Mosse et al. 2011).

Finally, the allochthonous bacteria present in the WWs occupied the BSF surface sediments transiently, without substantial proliferation, as observed in other environments (Berthe et al. 2008; Ramond et al. 2008, 2009). However, at the termination of the experiment, the community structure at the deep inlet of the BSF shared over $60 \%$ similarity with the microbial community in the WW (Fig. 2). Notwithstanding the fact that one T-RF may comprise more than one distinct bacterial ribotype (Blackwood et al. 2007), these results suggested that the influx of allochthonous bacteria from the impacting waste stream can be more significant than the modification of the autochthonous microbial population. This phenomenon has also been demonstrated in freshwater or estuarine sediments impacted by effluents (F'eray and Montuelle 2003; Ramond et al. 2008, 2009). In remediation processes, the introduction of allochthonous (micro) organisms is termed bioaugmentation, and its effectiveness in open systems, such as BSFs, remains debated (El Fantroussi and Agathos 2005); notably as numerous parameters may inhibit the growth and colonization of allochthonous bacteria in soil environments (reviewed by Vogel 1996). Nevertheless, our results suggest that in a specific BSF niche (deep inlet), long term WW contamination of BSFs (112 days) led to colonization by WW allochthonous bacteria, that is, that successful bio-augmentation was achieved.

\section{Conclusions}

CWs present a convenient, environmental friendly and cost-effective alternative method for the treatment of organic-rich waste streams. Here, we have demonstrated that simplified CWs, in the form of BSFs, can be alternatives to treat WW effectively as high COD, phenolics and salt removal efficiencies were achieved. This study thus lays the groundwork for the use of BSF systems to treat WW in wine-making regions where land is available, such as the Western Cape area in South Africa. Indeed, to completely validate such treatment process, long-term and replicate studies are now required. Finally, this study is the first to our knowledge proving that BSF microbial communities are significantly impacted by WW depending on their spatial locations, probably due to the toxicity of the influent stream (high COD, phenolic content and low $\mathrm{pH}$ ), but also by the allochthonous bacteria present in the WW. The high removal performances observed throughout the study suggested that the selected microbial communities were nevertheless able to tolerate and participate in the degradation of the WW discharge. Future work investigating and identifying the members of the WW-selected BSF bacterial communities is recommended, as once isolated such bacteria may be of great interest in bioaugmentation technologies aiming to remediate WW.

\section{Acknowledgements}

This study was funded by the Water Research Commission of South Africa (WRC project K5/1725: Health for purpose in wetlands).

\section{http://repository.uwc.ac.za}




\section{References}

Allison, S.D. and Martiny, J.B.H. (2008) Resistance; resilience, and redundancy in microbial communities. PNAS 105, 11512-11519.

Arienzo, M., Christen, E.W. and Quayle, W.C. (2009) Phytotoxicity testing of winery wastewater for constructed wetland treatment. J Hazard Mater 169, 94-99.

Berthe, T., Touron, A., Leloup, J., Deloffre, J. and Petit, F. (2008) Faecal-indicator bacteria and sedimentary process in estuarine mudflats (Seine, France). Mar Pollut Bull 57, $59-67$.

Blackwood, C.B., Hudleston, D., Zak, D.R. and Buyer, J.S. (2007) Interpreting ecological diversity indices applied to terminal restriction fragment length polymorphism data: insights from simulated microbial communities. Appl Environ Microbiol 73, $5276-5283$.

Bryson, G.M. and Barker, A.V. (2002) Sodium accumulation in soils and plants along Massachusetts roadsides. Commun Soil Sci Plant Anal 33, 67-78.

Clarke, K. (1993) Non-parametric multivariate analysis of changes in community structure. Aust J Ecol 18, 117-143.

Culman, S.W., Bukowski, R., Gauch, H.G., Cadillo-Quiroz, H. and Buckley, D.H. (2009) TREX: software for the processing and analysis of T-RFLP data. BMC Bioinformatics $10,171$.

El Fantroussi, S. and Agathos, S.N. (2005) Is bioaugmentation a feasible strategy for pollutant removal and site remediation? Curr Opin Microbiol 8, 268-275.

Faulwetter, J.L., Gagnon, V., Sundberg, C., Chazarenc, F., Burr, M.D., Brisson, J., Camper, A.K. and Stein, O.R. Journal of (2009) Microbial processes influencing performance of treatment wetlands: a review. Ecol Eng 35, 987-1004.

F'eray, C. and Montuelle, B. (2003) Chemical and microbial hypothesis explaining the effect of wastewater treatment plant discharges on the nitrifying communities in freshwater sediment. Chemosphere 50, 919-928.

Feris, K., Mackay, D., De Sieyes, N., Chakraborty, I., Einarson, M., Hristova, K. and Scow, K. (2008) Effect of ethanol on microbial community structure and function during natural attenuation of benzene, toluene, and o-xylene in a sulfate-reducing aquifer. Environ Sci Technol 42, 2289-2294.

Ferry, J.G. (1992) Methane from acetate. J Bacteriol 174, 5489-5495.

Francis, A.J. (1982) Effects of acidic precipitation and acidity on soil microbial processes. Water Air Soil Pollut 18, 375-394.

Gadd, G.M. (2010) Metals, minerals and microbes: geomicrobiology and bioremediation. Microbiology 156, 609-643.

Grismer, M.E., Tausendschoen, M. and Shepherd, H.L. (2001) Hydraulic characteristics of a subsurface flow constructed wetland for winery effluent treatment. Water Environ Res 73, 466-477.

Grismer, M.E., Carr, M.A. and Shepherd, H.L. (2003) Evaluation of constructed wetland treatment performance for winery wastewater. Water Environ Res 75, 412-421.

Haberl, R., Grego, S., Langergraber, G., Kadlec, R.H., Cicalini, A.-R., Martins Dias, S., Novais, J.M., Gerth, A. et al. (2003) Constructed wetlands for the treatment of organic pollutants. J Soil Sediments 3, 109-124. 
Haig, S.J., Collins, G., Davies, R. L., Dorea, C.C. and Quince, C. (2011) Biological aspects of slow sand filtration: past, present and future. Water Sci Technol: Water Supply 11, 468472.

Hammer, Ø., Harper, D.A.T. and Ryan, P.D. (2001) PAST: paleontological statistics software package for education and data analysis. Palaeontolo Electron 4, 9.

Hartman, V.H., Richardson, C.J., Vilgalys, R. and Bruland, G.L. (2008) Environmental and anthropogenic controls over bacterial communities in wetland soils. PNAS 105, $17842-17847$.

Herouvim, E., Akratos, C.S., Tekerlekopoulou, A. and Vayenas, D.V. (2011) Treatment of olive mill wastewater in pilot-scale vertical flow constructed wetlands. Ecol Eng 37, 931-939.

Lehmann, R.G., Cheng, H.H. and Harsh, J.B. (1986) Oxidation of phenolic acids by soil iron and manganese oxides. Soil Sci Soc Am J 51, 352-356.

Lucassen, E.C.H.E.T., Bobbink, R., Smolders, A.J.P., van der Ven, P.J.M., Lamers, L.P.M. and Roelofs, J.G.M. (2002) Interactive effects of low pH and high ammonium levels responsible for the decline of Cirsium dissectum (L.) Hill. Plant Ecol 165, 45-52.

Madigan, M.T. and Oren, A. (1999) Thermophilic and halophilic extremophiles. Curr Opin Microbiol 2, 265-269.

Malandra, L., Wolfaardt, G., Zietsman, A. and Viljoen-Bloom, M. (2003) Microbiology of a biological contactor for winery wastewater treatment. Water Res 37, 4125-4134.

Mastorp, H., Guan, X. and Gong, P. (2000) Relationship between dsDNA, chloroform labile $\mathrm{C}$ and ergosterol in soils of different organic matter contents and $\mathrm{pH}$. Soil Biol Biochem 32, 879-882.

Mengoni, A., Tatti, E., Decorosi, F., Viti, C., Bazzicalupo, M. and Giovannetti, L. (2005) Comparison of $16 \mathrm{~S}$ rRNA and $16 \mathrm{~S}$ rDNA T-RFLP approaches to study bacterial communities in soil microcosms treated with chromate as perturbing agent. Microb Ecol 50, 375-384.

Mosse, K.P.M., Patti, A.F., Christen, E.W. and Cavagnaro, T.R. (2010) Winery wastewater inhibits seed germination and vegetative growth of common crop species. J Hazard Mater 180, 63-70.

Mosse, K.P.M., Patti, A.F., Christen, E.W. and Cavagnaro, T.R. (2011) Review: winery wastewater quality and treatment options in Australia. Aust J Grape Wine Res 17, 111112.

Moussa, M.S., Sumanasekera, D.U., Ibrahim, S.H., Lubberding, H.J., Hooijmans, C.M., Gijzen, H.J. and van Loosdrecht,

M.C.M. (2006) Long term effects of salt on activity, population structure and floc characteristics in enriched bacterial cultures of nitrifiers. Water Res 40, 1377-1388.

Polubesova, T., Eldad, S. and Chefetz, B. (2010) Adsorption and oxidative transformation of phenolic acids by Fe(III)- Montmorillonite. Environ Sci Technol 44, 4203-4209.

Ramakrishna, D.V. and Viraraghavan, T. (2005) Environmental impact of chemical deicers - a review. Water Air Soil Pollut 166, 49-63.

Ramond, J.-B., Berthe, T., Lafite, R., Deloffre, J., Ouddane, B. and Petit, F. (2008) Relationships between hydrosedimentary processes and occurrence of mercury- 
resistant bacteria (merA) in estuary mudflats (Seine, France). Mar Pollut Bull 56, $1168-1176$.

Ramond, J.-B., Berthe, T., Duran, R. and Petit, F. (2009) Comparative effects of mercury contamination and wastewater effluent input on Gram-negative merA gene abundance in mudflats of an anthropized estuary (Seine, France): a microcosm approach. Res Microbiol 160, 10-18.

Ramond, J.-B., Welz, P.J., Cowan, D.A. and Burton, S.G. (2012) Microbial community structure stability, a key parameter in monitoring the development of constructed wetland mesocosms during start-up. Res Microbiol 163, 28-35.

South African Wine Industry (SAWIS). (2010) South African Wine Industry Statistics Booklet Nr 34. Paarl. South Africa: South African Wine Industry.

Serrano, L., de la Vargo, D., Ruiz, I. and Soto, M. (2010) Winery wastewater treatment in a hybrid constructed wetland. Ecol Eng 37, 744-753.

Shepherd, H.L., Grismer, M.E. and Tchobanoglous, G. (2001a) Treatment of high-strength winery wastewater using a subsurface-flow constructed wetland. Water Environ Res $73,394-403$.

Shepherd, H.L., Tchobanoglous, G. and Grismer, M.E. (2001b) Time-dependant model for chemical oxygen demand removal in subsurface-flow constructed wetland for winery wastewater treatment. Water Environ Res 73, 597-606.

Sheridan, C.M., Glasser, D., Hildebrand, D., Petersen, J. and Rohwer, J. (2011) An annual and seasonal characterisation of winery effluents in South Africa. S Afr J Enol Vitic 32, $1-8$.

Slinkard, K. and Singleton, V.L. (1977) Total phenol analysis: automation and comparison with manual methods. Am J Enol Vitic 28, 49-55.

Stottmeister, U., Wießner, A., Kuschk, P., Kappelmeyer, U., K€stner Bederski, B., MÆller, R.A. and Moorman, H. (2003) Effects of plants and microorganisms in constructed wetlands for wastewater treatment. Biotechnol Adv 22, 93-117.

Tanner, C.C. (2001) Plants as ecosystem engineers in subsurface-flow treatment wetlands. Water Sci Technol 44, 9-17.

Truu, M., Johanson, J. and Truu, J. (2009) Microbial biomass, activity and community composition in constructed wetlands. Sci Total Environ 407, 3958-3971.

Verheye, W. (2002) Soil and soil sciences. Land Use, Land Cover and Soil Sciences Encyclopedia of Life Support Systems (EOLSS) Volume. Oxford, UK: VIE UNESCO Publishing - EOLSS Publishers.

Verhoeven, J.T.A., Arheimer, B., Yin, C. and Hefting, M.M. (2006) Regional and global concerns over wetlands and water quality. Trends Ecol Evol 21, 96-103.

Vogel, T.M. (1996) Bioaugmentation as a soil bioremediation approach. Curr Opin Biotechnol 7, 311-316.

Vymazal, J. (2009) The use constructed wetlands with horizontal sub-surface flow for various types of wastewaters. Ecol Eng 35, 1-17.

Welz, P.J., Ramond, J.-B., Cowan, D.A. and Burton, S.G. (2012) Phenolic removal processes in biological sand filters, sand columns and microcosms. Bioresour Technol 119,262-269. 
Yagi, J.M., Neuhauser, E.F., Ripp, J.A., Mauro, D.M. and Madsen, E.L. (2010) Subsurface ecosystem resilience: long-term attenuation of subsurface contaminants supports a dynamic microbial community. ISME $\mathrm{J} 4,131-143$.

Yong, R.N., Warkentin, B.P., Phadungchewit, Y. and Galvez, R. (1990) Buffer capacity and lead retention in some clay materials. Water Air Soil Pollut 53, 53-67.

Zhang, Z.-J., Chen, S.-H., Wang, S.-M. and Luo, H.-Y. (2011) Characterization of extracellular polymeric substances from biofilm in the process of starting-up a partial nitrification process under salt stress. Appl Microbiol Biotechnol 89, 1563-1571.

\section{Supporting Information}

Additional Supporting Information may be found in the online version of this article: Table S1 Sediment characterization of the biological sand filters. 